\title{
Effectiveness of fungal, bacterial and yeast antagonists for management of mango anthracnose (Colletotrichum gloeosporioides)
}

\author{
Adikshita Sharma ${ }^{1}$, Inder Mohan Sharma ${ }^{1}$, Monica Sharma ${ }^{1 *} \mathbb{D}$, Kishor Sharma ${ }^{1}$ and Amit Sharma ${ }^{2}$
}

\begin{abstract}
Background: Mango anthracnose, caused by Colletotrichum gloeosporioides, is one of the most important diseases of mango crop. It mainly attacks leaves, flowers, young fruits and twigs and also appears as a post-harvest disease of ripened fruits. Application of bio-control agents has huge potential in plant disease management. The goal of the present research was to establish the potential of individual and combined bio-control agents for the management of mango anthracnose under in vitro and under field conditions.

Results: The antagonistic reaction of six fungi, six bacteria and nine yeasts against C. gloeosporioides on potato dextrose agar medium and malt extract agar medium was observed among which Trichoderma harzianum was found to be the most efficient with $89.26 \%$ mycelial growth inhibition. Evaluation of bio-control agents against anthracnose disease development on mango fruit revealed that dip treatment of mango fruits in spore suspension $\left(1.2 \times 10^{4} \mathrm{cfu} /\right.$ $\mathrm{ml}$ ) of T. harzianum for $5 \mathrm{~min}$ was the most effective and provided disease control to the tune of $81.67 \%$. Combined application of effective bio-control agents as a post-harvest fruit dip treatment was also evaluated against the mango anthracnose on mango fruits, where the treatment of T. harzianum + Pichia anomala was very effective with 93.39\% disease control. Under field conditions, three consecutive sprays of T. harzianum, starting with the initiation of disease on leaves, followed by other two sprays at an interval of 15 days during 2015 and 2016 were found the best for the management of mango anthracnose disease both on leaves and on fruits at two locations.

Conclusions: The combined and individual applications of bio-control agents, viz. T. harzianum, Bacillus subtilis and $P$. anomala, through foliar spray or by fruit dip had the potential to control mango anthracnose. The bio-formulations of these bio-control agents had the potential to replace chemical fungicides and also protect the natural environment, thus playing a significant role in integrated disease management.
\end{abstract}

Keywords: Eco-friendly, Colletotrichum gloeosporioides, Antagonistic, Bio-control agents, Internal transcribed spacer

\section{Background}

Mango, Mangifera indica L., popularly known as 'King of fruits' or 'apple of tropics' belonging to the family Anacardiaceae is a major fruit crop in tropical and subtropical regions (Berardini et al. 2005). Mango is exposed to a number of diseases; some of them are highly devastating,

\footnotetext{
*Correspondence: dmonicasharma@gmail.com

${ }^{1}$ Department of Plant Pathology, Dr YS Parmar University of Horticulture

\& Forestry (Solan), Nauni, Himachal Pradesh, India

Full list of author information is available at the end of the article
}

which limit the production and productivity of mango crop. Among the diseases of mango, anthracnose caused by Colletotrichum gloeosporioides is the most ruinous diseases. It mainly attacks leaves, flowers, young fruits and twigs and also appears as a post-harvest disease of harvested fruits. Black, irregular shaped and slightly sunken spots appear on leaves and fruits, which gradually increase in size and cause leaf-spots, blossom blight, fruit spots and eventually fruit rot (Additional file 1: Fig. 1s). Under wet or very humid environment which are prevalent in most mango growing areas, high disease incidence 
of up to $100 \%$ on fruits could be observed. Unfortunately, the extensive use of chemical fungicides remains the main means for controlling most diseases including mango anthracnose, but their use has resulted in the accumulation of toxic compounds potentially hazardous to humans and the environment (Saeed et al. 2016). Due to the fungicide-related risks, there has been urgent need for the development of alternative and effective methods for the management of plant diseases (Ma and Michailides 2005). Cultural practices, bio-control agents (BCAs) and natural compounds have the potential to use for disease management to avoid the use of chemical fungicides. Therefore, the use of micro-organisms, which are native to the same environmental conditions, should be effectively used to control the pathogen growth or reduce its population to its best level (Syed et al. 2018). Bio-control agents indirectly regulate and lower the adverse effect of different biotic stress by enhancing systemic resistance in plant due to production of antifungal bacteriocins, metabolites, antibiotics, iron chelating siderophores and lytic enzymes (Saraf et al. 2014). Plant growth activities are promoted by different bio-control agents, which involve providing plants with several phyto-hormones, helping in absorption of several essential nutrients directly from the environment for plant growth, nitrogen fixation, mineral solubilization, chelation of iron, production of siderophores, plant growth hormones, etc. (Saharan and Nehra 2011). Recently, the production of pectinase and chitinase enzymes by Trichoderma longibrachiatum, T. asperellum, and T. atroviride against Rhizoctonia solani had been demonstrated (Sallem et al. 2021). These three species also solubilized phosphors and produced siderophores and indole acetic acid, which helped the augmentation of growth of the soybean plants. Thus, the present investigation was undertaken to evaluate the potential of fungal, bacterial and yeast antagonists for the management of mango anthracnose.

\section{Methods}

\section{Isolation of pathogen}

The fungal pathogen, C. gloeosporioides, was isolated from mango fruits and leaves showing anthracnose symptoms by adopting the standard procedures (Dhingra and Sinclair 1995). On the basis of cultural and morphological characters such as mycelial colour and conidial characteristics, the fungus was identified (Barnett 1972).

\section{Molecular identification of Colletotrichum gloeosporioides}

The genomic DNA of fungal pathogen was isolated by practicing the cetyl-trimethyl-ammonium-bromide (CTAB; Sigma Chemical., St. Louis, USA) method (Murray and Thompson 1980) with little modifications. Quantity of isolated DNA was checked by gel electrophoresis on $0.8 \%$ of agarose gel. A DNA region encoding for internal transcribed spacer (ITS) was amplified from the genomic DNA of pathogen in polymerase chain reaction (PCR) using universal primers ITS1 (5'-TCC GTA GGT GAA CCT GCG-3') and ITS4 (5'-CTC CGC TTA TTG ATA TGC T- $3^{\prime}$ ). PCR was performed in $25 \mu$ reaction volume containing 1.0 unit Taq DNA polymerase, dNTP mix $(0.2 \mathrm{~mm}$ each of dCTP, dGTP, dATP and dTTP), $1 \times$ PCR buffer $(20 \mathrm{~mm}$ Tris- $\mathrm{HCl} \mathrm{pH} \mathrm{8.4,50} \mathrm{mm}$ $\left.\mathrm{KCl}, 1.5 \mathrm{~mm} \mathrm{MgCl}_{2}\right), 1.0 \mu \mathrm{m}$ each primer and 25-50 ng of genomic DNA. PCR was performed in a thermocycler (Veriti, Applied Biosystems) with a total of 40 cycles. Each cycle consisted of initial denaturation at $94{ }^{\circ} \mathrm{C}$ for 5 min followed by 40 cycles of denaturation at $94{ }^{\circ} \mathrm{C}$ for $30 \mathrm{~s}$, annealing at $58{ }^{\circ} \mathrm{C}$ for $30 \mathrm{~s}$, extension at $72{ }^{\circ} \mathrm{C}$ for $1.5 \mathrm{~min}$ and final extension at $72{ }^{\circ} \mathrm{C}$ for $5 \mathrm{~min}$. Amplified PCR products were analysed on $1.2 \%$ gel in horizontal gel electrophoresis and observed in 'Ingenious Gel Documentation System (Syngene). The amplified PCR products were extracted from agarose gel with GeneJET Gel Extraction Kit (Thermo Scientific) by following manufacturer's protocol. For DNA sequencing, purified PCR product was outsourced to Xcelris Genomics, India, under standard conditions. Sequenced data were analysed with the help of bioinformatics tools, and homologous sequences were retrieved from NCBI-BLAST (Basic Local Alignment Search Tool). Evolutionary analyses were carried out in MEGA X (Kumar et al. 2018). The phylogenetic analysis of sequences was analysed by using the minimum evolution method and bootstrap.

\section{Isolation and identification of bio-control agents}

Leaves and fruits of mango were collected from different major mango growing areas of districts of Kangra, Mandi, Sirmour and Shimla of Himachal Pradesh. Fungal bio-control agents, viz. Trichoderma harzianum isolate 1 , $T$. harzianum isolate $2, T$. koningii, $T$. hamatum, $T$. viride and T. virens, and bacterial bio-control, viz. Pseudomonas fluorescens, P. putida, Bacillus subtilis isolate 1, B. subtilis isolate $2, B$. subtilis isolate 3 and $B$. subtilis isolate 4 , were isolated from phylloplane and fructoplane of mango on PDA (for fungi) and nutrient agar medium (for bacteria) by following the serial dilution technique (Johnson 1957). The isolated Trichoderma spp. were identified on the basis of morphological characters documented in taxonomic keys (Rifai 1969). The isolated bacteria were identified on the basis of morphological, cultural characteristics and biochemical tests (Aneja 2003). Nine antagonistic yeasts, viz. Debaryomyces hansenii (MTCC Code: 9882), Aureobasidium pullulans (MTCC Code: 153), Hanseniaspora uvarum (MTCC Code: 408), $H$. occidentalis (MTCC Code: 628), Cryptococcus laurentii (MTCC Code: 3953), Pichia anomala (MTCC Code: 
237), Rhodotorula phylloplana (MTCC Code: 2748) P. guilliermondii (MTCC Code: 1005) and Candida sake (MTCC Code: 229), were procured from CSIR-Institute of Microbial Technology (IMTECH), Chandigarh, India. These were grown on malt yeast agar (MYA) medium (malt extract $=3 \mathrm{~g}$, yeast extract $=3 \mathrm{~g}$, peptone $5 \mathrm{~g}$, glucose $=10 \mathrm{~g}$, agar-agar $20 \mathrm{~g}$, distilled water $=1 \mathrm{~L}, \mathrm{pH}=7.0$ ) as suggested by CSIR- IMTECH Chandigarh, India.

\section{In vitro antagonism of bio-control agents against $C$. gloeosporioides}

Antagonistic activities of six promising fungal bio-control agents, viz. Trichoderma harzianum isolate 1, T. harzianum isolate 2, T. koningii, T. hamatum, T. viride and T. virens, were evaluated against the mycelia growth of C. gloeosporioides by adopting the dual culture method on PDA medium under in vitro (Huang and Hoes 1976). Six bacterial bio-control agents, viz. Pseudomonas fluorescens, $B$. putida, Bacillus subtilis isolate $1, B$. subtilis isolate 2, B. subtilis isolate 3 and B. subtilis isolate 4, and nine yeast bio-control agents, viz. Debaryomyces hansenii, Aureobasidium pullulans, Hanseniaspora uvarum, H. occidentalis, Cryptococcus laurentii, Pichia anomala, Rhodotorula phylloplana, P. guilliermondii and Candida sake against C. gloeosporioides were evaluated by following the streak plate method (Utkhede and Rahe 1983) on malt extract agar (MEA) medium. For each treatment, three replications were maintained and the Petri plates were incubated at $25 \pm 2{ }^{\circ} \mathrm{C}$ in BOD incubator. The colony diameter of the pathogenic fungus was measured, 7 days after inoculation. The percentage of mycelial growth inhibition of the test pathogen was calculated according to the formula given by Vincent (1947):

$$
\mathrm{I}=\{(\mathrm{C}-\mathrm{T}) / \mathrm{C}\} \times 100
$$

where I-percentage of inhibition in mycelial growth; $\mathrm{C}$-linear mycelial growth in control $(\mathrm{mm})$; $\mathrm{T}$-linear mycelial growth in treatment $(\mathrm{mm})$.

\section{Evaluation of effective bio-control agents against anthracnose disease on harvested mango fruits}

The most effective bio-control agents were evaluated for their comparative efficacies against anthracnose on harvested mango fruits. Fungal bio-control agents, viz. $T$. harzianum isolate 1 and T. viride, were mass multiplied using molasses yeast extract broth (Prasad and Rangeshwaram 2000), whereas bacterial bio-control agents, namely $P$. fluorescens and $B$. subtilis isolate 1 , were grown in nutrient broth and yeast antagonists $P$. anomala and $R$. phylloplana were prepared in malt extract broth at $28 \pm 1{ }^{\circ} \mathrm{C}$ in BOD incubator shaker for three days. Then, the solution of above bio-control agents of different origins, i.e. fungal, bacterial and yeast, was prepared with the concentration of $1.2 \times 10^{4} \mathrm{cfu} / \mathrm{ml}$ for fungi, $1.2 \times 10^{8} \mathrm{cfu} /$ $\mathrm{ml}$ for bacteria and $1.2 \times 10^{8} \mathrm{cfu} / \mathrm{ml}$ for yeast bio-control agents. Mango fruits cv. Dashehari of uniform size and shape were procured from orchard for evaluation. Fruits were dipped in $5 \%$ solution of these bio-control agents for $5 \mathrm{~min}$ and then air-dried in the laboratory. Sticker, namely Mixin (Biostadt India Limited, India), was added @ $0.2 \%$ in the solution to ensure the proper and uniform sticking of the solution on the surface of the fruit. The efficacy of bio-agents was compared with fruit dipped in distilled water as control. These fruits were then inoculated with the test pathogen, i.e. C. gloeosporioides, by the pin-prick method using $5 \mu \mathrm{l}$ spore suspension $\left(1 \times 10^{6}\right.$ conidia $/ \mathrm{ml}$ ) and incubated at room temperature $(25-$ $28{ }^{\circ} \mathrm{C}$ ). Observations on efficacies of these treatments against mango anthracnose were recorded after 7,15 , 21,28 days of inoculation by adopting $0-5$ disease scale mentioned in Table 1 (Sundravadana et al. 2007). Percentage disease index (PDI) was calculated by adopting the following formula devised by Mckinney (1923): percentage disease index $(\mathrm{PDI})=$ Sum of all numerical ratings/ Number of samples observed $\times$ Maximum disease grade $\times 100$.

\section{Evaluation of effective bio-control agents against mango anthracnose under field conditions}

The most effective bio-control agents were further evaluated under natural epiphytotic conditions on mango plants growing at two locations: location I-Regional Horticultural Research and Training Station (RHR\&TS), Dhaula Kuan (Sirmour) situated on latitude and longitude of $30.4620^{\circ} \mathrm{N}, 77.4817^{\circ} \mathrm{E}$ at an elevation of $468 \mathrm{~m}$ amsl (above mean sea level); location II-Regional Horticulture Research and Training Station (RHR\&TS), Jachh (Nurpur) situated on latitude and longitude of $32.3001^{\circ}$ $\mathrm{N}, 75.8853^{\circ} \mathrm{E}$ at an elevation of $428 \mathrm{~m}$ amsl. The mango plants of cultivar 'Dashehari' of equal age were randomly selected at both locations for two consecutive years 2015 and 2016. Each bio-control agent was sprayed thrice starting with the initiation of disease symptoms on leaves

Table 1 Disease rating scale for mango anthracnose disease

\begin{tabular}{lll}
\hline Grade & \multicolumn{2}{l}{ Per cent area of infection } \\
\cline { 2 - 3 } & Leaves & Fruits \\
\hline 0 & 0 & No infection \\
1 & -20 & Upto 5 \\
2 & $21-40$ & $6-10$ \\
3 & $41-60$ & $11-20$ \\
4 & $61-80$ & $21-50$ \\
5 & $>80$ & $>50$ \\
\hline
\end{tabular}




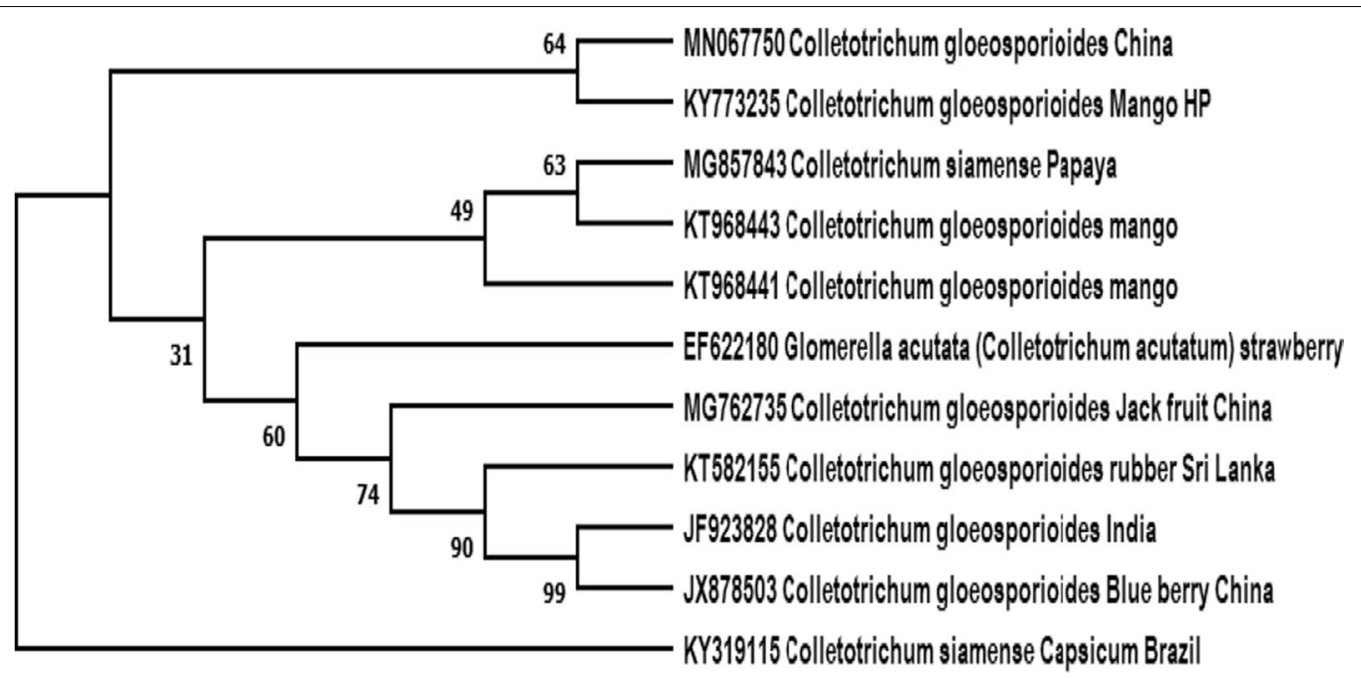

Fig. 1 Phylogenetic tree based on the ITS sequences showing the relationship between sequences of different Colletotrichum spp. and similar other sequences deposited in the NCBI GenBank, USA

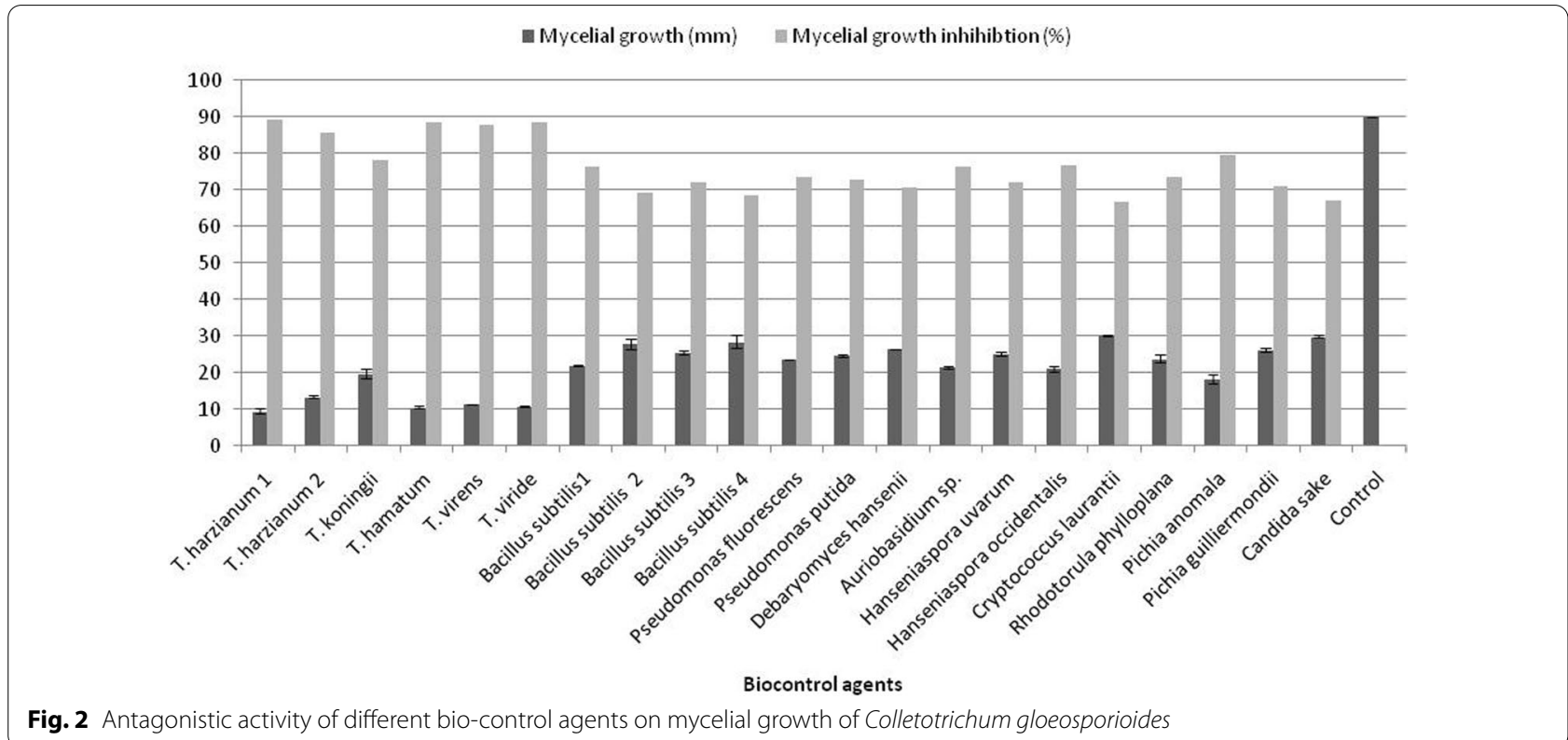

(19 July in 2015, 11 July in 2016 at Dhaula Kuan, 20 July in 2015, 15 July in 2016 at Jachh), followed by other two sprays at an interval of 15 days. Experiment was laid in randomized block design (RBD) with three replications for each treatment. The water-sprayed trees served as control. The observations of disease severity on leaves and fruits were recorded by adopting $0-5$ disease rating scale mentioned in Table 1 (Sundravadana et al. 2007). Disease severity was recorded on leaves after 15 days of last spray. Further, the percentage of disease index (PDI) for each treatment was calculated separately.
Integration of different bio-control agents against anthracnose diseases on harvested mango fruits The best treatment from the bio-control agents was integrated with a view to evaluate their combined effect on management of anthracnose on harvested mango fruits. Five percentage of concentration from each liquid formulation of fungal $\left(1.2 \times 10^{4} \mathrm{cfu} / \mathrm{ml}\right)$, bacterial $\left(1.2 \times 10^{8} \mathrm{cfu} / \mathrm{ml}\right)$ and yeast $\left(1.2 \times 10^{8} \mathrm{cfu} / \mathrm{ml}\right)$ antagonists was prepared. To apply a combination of bio-control agents, mango fruits were first dipped in solution of one bio-control agent for $5 \mathrm{~min}$, followed by air drying 


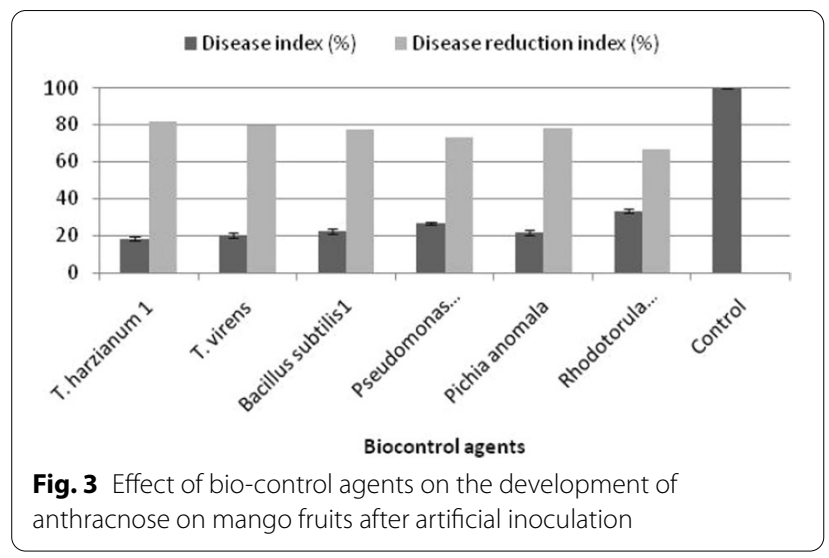

for $30 \mathrm{~min}$ and subsequently dipped in second bio-control agent for $5 \mathrm{~min}$, followed by air drying. Sticker, namely Mixin (0.2\%), was also added in the solution of bio-control formulations. Three replications were maintained for each treatment. Thereafter, the treated fruits were challenge-inoculated with test pathogen by the pinprick method as described above. Observations on the efficacy of these treatments against mango anthracnose were recorded after 7, 15, 21, 28 days of inoculation by following 0-5 disease rating scale. Percentage disease and decay reduction indices for each treatment were also calculated. The treatment details of the integrated trial were as: $\mathrm{T}_{1}:$ T. harzianum $(5 \%)+$ B. subtilis $(5 \%): \mathrm{T}_{2}: T$. viride $(5 \%)+B$. subtilis (5\%): $\mathrm{T}_{3}:$ T. hamatum $(5 \%)+P$. fluorescens (5\%): $\mathrm{T}_{4}:$ T. harzianum (5\%) + Pichia anomala (5\%): $\mathrm{T}_{5}: T$. virens + P.fluorescens (5\%): $\mathrm{T}_{6}:$ T. harzianum $(5 \%)+$ Hanseniaspora uvarum (5\%): $T_{7}:$ T. viride $(5 \%)+P$. anomala (5\%): $T_{8}: T$. viride (5\%) $+H$. uvarum (5\%): $T_{9}: T$. hamatum (5\%) +B. subtilis (5\%): $\mathrm{T}_{10}$ : Control.

\section{Statistical analysis}

The data gathered from laboratory and field experiments were dispensed to appropriate statistical analysis using standard procedures as specified by Gomez and Gomez (1984). Critical differences (CD) among the treatments in various experiments at $5 \%$ level were also calculated to ascertain the least significant differences (LSD).

\section{Results}

Identification of Colletotrichum gloeosporioides

On the basis of mycelial and conidial characteristics, the isolated fungus was identified as $C$. gloeosporioides (Additional file 1: Fig. 2s). To further confirm the identity of fungus, a DNA region coding for ITS1, ITS2 and 5.8S rRNA gene was amplified from the genomic DNA using primer combination ITS 1 and ITS 4. A unique band of $560 \mathrm{bp}$ was obtained. The sequence of the region was compared with NCBI-BLAST database. BLAST search revealed that closest sequence was of $C$. gloeosporioides. The sequence of the C. gloeosporioides of the present study was submitted to National Centre for Biotechnology Information (NCBI) and its accession number is KY773235.

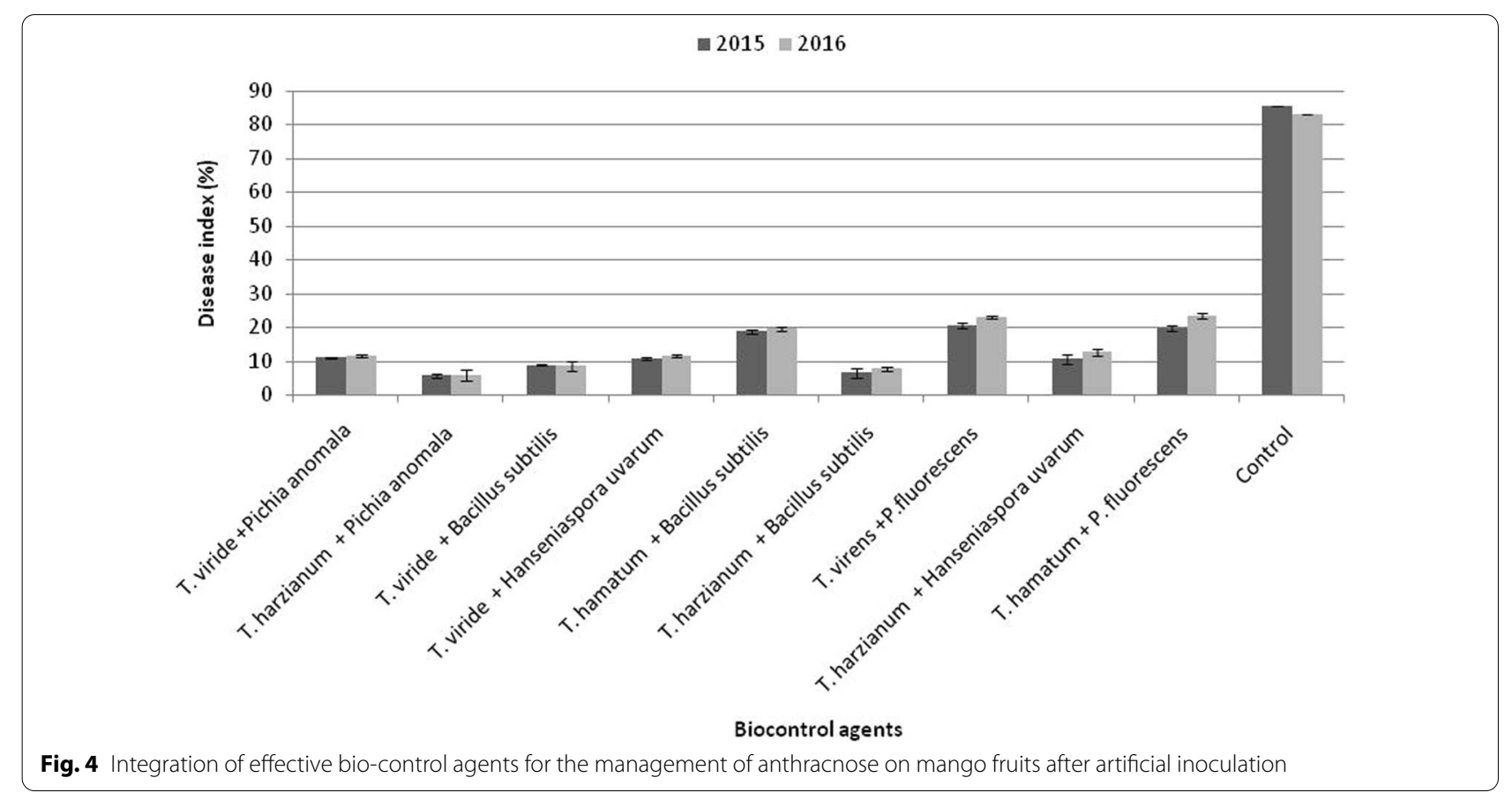


Table 2 Integration of effective bio-control agents on development of anthracnose on mango fruits after artificial inoculation

\begin{tabular}{|c|c|c|c|c|c|c|}
\hline \multirow[t]{2}{*}{ Treatment no. } & \multirow[t]{2}{*}{ Treatment } & \multirow[t]{2}{*}{ Conc. (\%) } & \multicolumn{3}{|c|}{ Per cent disease index (PDI) } & \multirow{2}{*}{$\begin{array}{l}\text { Disease } \\
\text { control } \\
\text { (\%) }\end{array}$} \\
\hline & & & 2015 & 2016 & Mean & \\
\hline $\mathrm{T}_{1}$ & T. viride + Pichia anomala & $5+5$ & $10.82(19.14)$ & $11.41(19.70)$ & 11.12 & 86.98 \\
\hline $\mathrm{T}_{2}$ & T. harzianum + Pichia anomala & $5+5$ & $5.62(13.50)$ & $5.67(13.67)$ & 5.65 & 93.39 \\
\hline $\mathrm{T}_{3}$ & T. viride + Bacillus subtilis & $5+5$ & $8.79(17.15)$ & $8.44(16.83)$ & 8.62 & 89.91 \\
\hline $\mathrm{T}_{4}$ & T. viride + Hanseniaspora uvarum & $5+5$ & $10.56(18.92)$ & $11.52(19.78)$ & 11.04 & 85.00 \\
\hline $\mathrm{T}_{5}$ & T. hamatum + Bacillus subtilis & $5+5$ & $18.63(25.53)$ & $19.45(26.13)$ & 19.04 & 87.08 \\
\hline $\mathrm{T}_{6}$ & T. harzianum + Bacillus subtilis & $5+5$ & $6.56(14.73)$ & $7.58(15.87)$ & 7.07 & 91.72 \\
\hline $\mathrm{T}_{7}$ & T. virens + P.fluorescens & $5+5$ & $20.41(26.82)$ & $22.90(28.57)$ & 21.66 & 74.64 \\
\hline $\mathrm{T}_{8}$ & T. harzianum + Hanseniaspora uvarum & $5+5$ & $10.63(18.98)$ & $12.48(20.64)$ & 11.56 & 86.47 \\
\hline $\mathrm{T}_{9}$ & T. hamatum + P. fluorescens & $5+5$ & $19.71(26.57)$ & $23.26(28.81)$ & 21.49 & 74.84 \\
\hline $\mathrm{T}_{10}$ & Control & - & $85.42(67.57)$ & $83.02(65.07)$ & 85.42 & 0 \\
\hline
\end{tabular}

Figures in parentheses are angular transformed values

The phylogenetic analysis with the minimum evolution approach revealed that the isolated pathogen with NCBI accession number KY773235 clustered together with $C$. gloeosporioides MN067750 with bootstrap value of 64\% in cluster I (Fig. 1). Cluster II consisted of C. gloeosporioides from other hosts.

\section{Antagonistic activity of bio-control agents against $C$. gloeosporioides under in vitro}

The tested antagonists were found effective against the test pathogen with inhibition more than 50\% growth of C. gloeosporioides. Fungal bio-control agent, T. harzianum isolate 1, was effective with $89.26 \%$ mycelial growth inhibition, and T. hamatum, T. viride, T. virens were found at par with each other. Bacterial bio-control agent $B$. subtilis isolate 1 was found effective with 76.30 per cent inhibition in mycelial growth and B. subtilis isolate $1, P$. fluorescens and P. putida were found at par with each other (Additional file 1: Fig. 3s). Among yeast bio-control agents, P. anomala was found to be the best with inhibition of $79.63 \%$ (Fig. 2).

\section{Evaluation of effective bio-control agents} against anthracnose disease on harvested mango fruits under laboratory conditions

T. harzianum isolate 1 effectively reduced the disease by $81.67 \%$ and was significantly superior over all the other bio-control agents (Additional file 1: Fig. 4s), whereas B. subtilis bacterial bio-control agent was the next best with $77.78 \%$ disease control when evaluated on harvested mango fruits under laboratory conditions (Fig. 3).

\section{Integration of different bio-control agents} against anthracnose disease on harvested mango fruits The combined treatment of T. harzianum (5\%)+Pichia anomala (5\%) was the most effective and provided 93.39\% disease control. It was followed by treatment of T. harzianum (5\%) + B. subtilis (5\%) with $91.72 \%$ disease control. The next best treatments in order were $T$. viride $(5 \%)+B$. subtilis $(5 \%)$ and T. hamatum + B. subtilis, which provided disease control to an extent of 89.91 and $87.08 \%$, respectively (Fig. 4, Table 2).

\section{Field evaluation of effective bio-control agents against mango anthracnose caused by $C$. gloeosporioides} Efficacy of the bio-control agents as spray application under field conditions showed that three successive sprays with $T$. harzianum isolate 1 at $5 \%$ concentration starting with initiation of disease (19 July in 2015, 11 July in 2016 at location-I, 20 July in 2015, 15 July in 2016 at location-II), followed by other two sprays at an interval of fifteen days, were the most effective at both the locations and reduced the disease to an extent of $59.91,54.77 \%$ disease control on leaves and 56.57, 52.66\% disease control on fruits, respectively (Tables 3 and 4). It was followed by $B$. subtilis $(54.89,52.95 \%$ on leaves, $54.24,50.91 \%$ on fruits), $T$. virens $(53.93,51.98 \%$ on leaves, $51.74,50.41 \%$ on fruits) and P. anomala $(47.55,47.48 \%$ on leaves, $45.59,42.76 \%$ on fruits), respectively. At both locations on leaves, minimum percentages of disease index of 26.67 and 30.59 were recorded with $T$. harzianum isolate 1 (Fig. 5). Analogically, at both locations on fruits, 


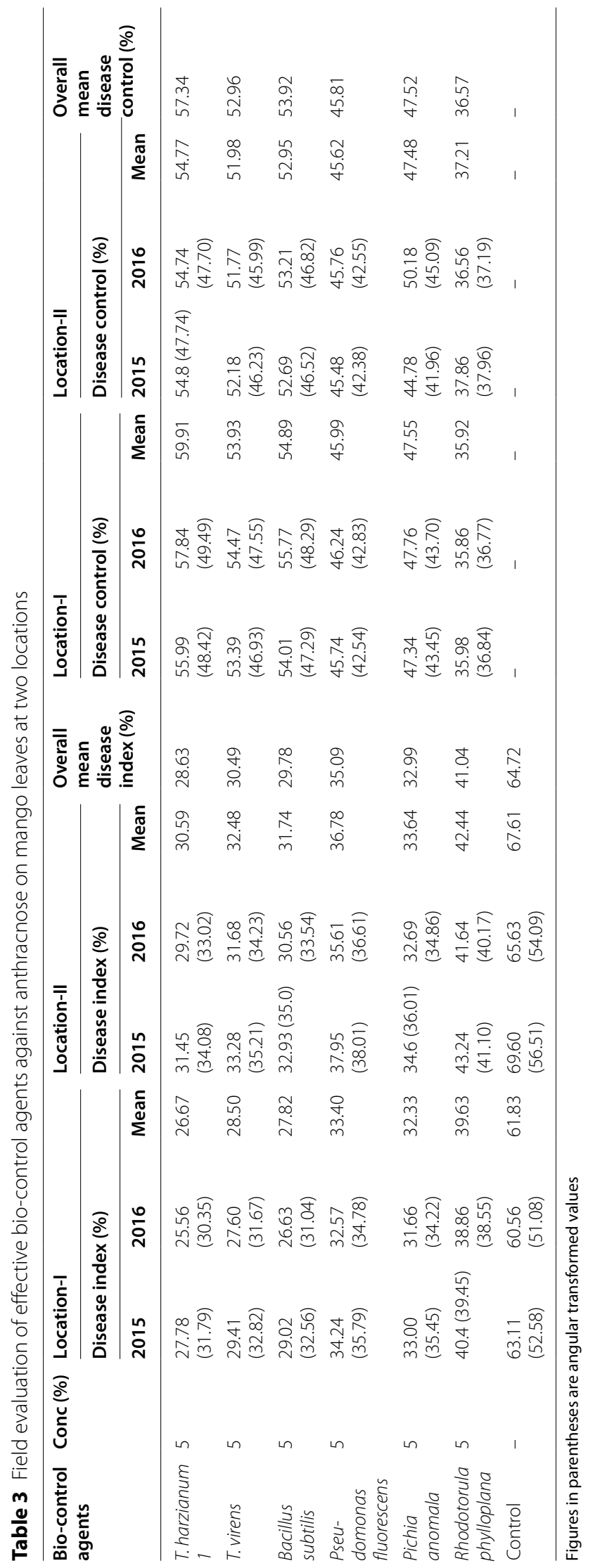




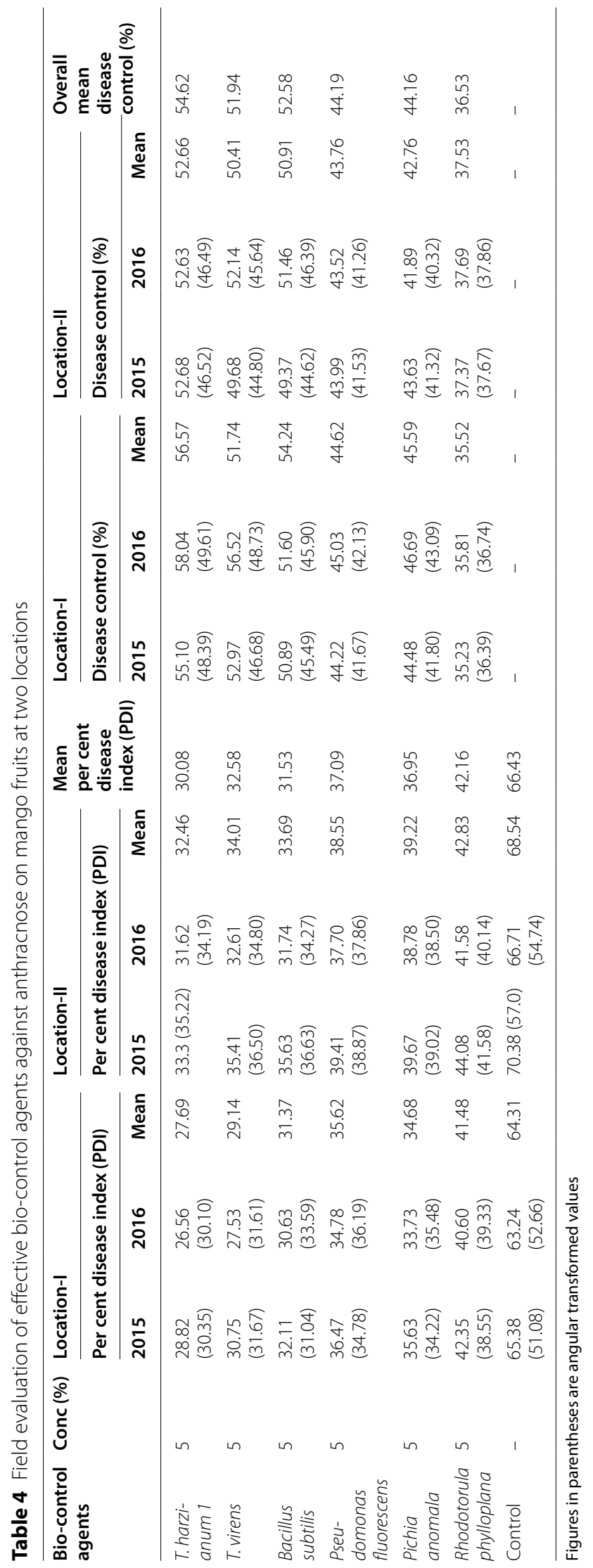




\section{Location I 2015 Location I 2016 - Location II 2015 Location II 2016}

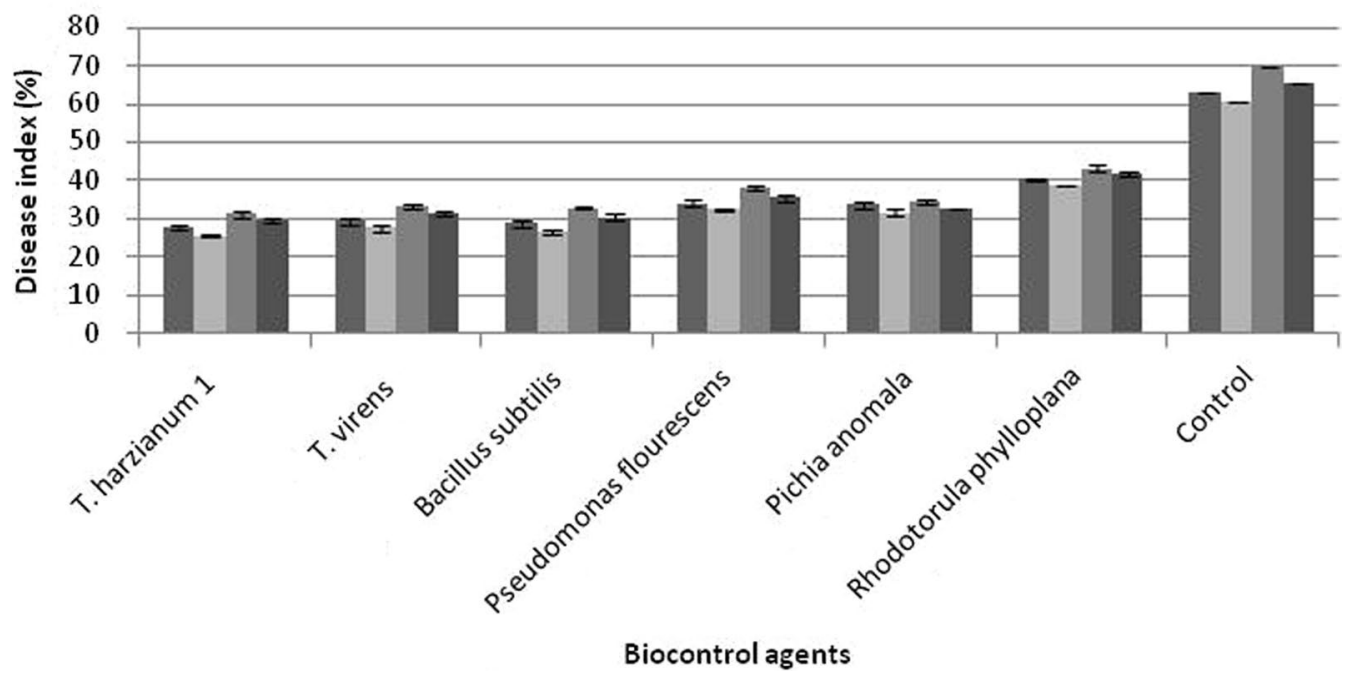

Fig. 5 Effect of bio-control agents on anthracnose development on mango leaves under field conditions

minimum percentages of disease indices of 27.69 and 32.46 were recorded with $T$. harzianum isolate 1 (Figs. 5, 6; Tables 3, 4).

\section{Discussion}

Different species of Trichoderma had been reported to be efficient in inhibiting mycelia growth of C. gloeosporioides causing mango anthracnose (Gud and Raut 2008). Seven fungi and two bacterial antagonists were screened against C. gloeosporioides, and it was found that T. harzianum exhibited a maximum inhibition, followed by P. fluorescens under in vitro conditions (Prabakar et al. 2008). Further, it was also reported that dipping of fruits in T. harzianum and P. fluorescens suspensions reduced anthracnose on mango fruits by 40.0 and $43.3 \%$, respectively. Udhayakumar and Usha Rani (2010) isolated nine bacterial isolates from different parts of mango, viz. leaves, fruits and blossom, and further evaluated their efficacy against $C$. gloeosporioides, which revealed that an isolate of $P$. fluorescens resulted in maximum inhibition in germination of conidia, maximum reduction in germ tube length and maximum inhibition in mycelial growth.

Trichoderma spp. provided antagonistic activity against plant pathogenic fungi by competition for nutrients, mycoparasitism and antibiosis. Trichoderma spp. hyperparasite formed coil, hooks or appressorium-like structures around the pathogen mycelium (Elad et al. 1983). Begum et al. (2008) observed that the Trichoderma isolates coiled around the hyphae of C. truncatum, which further restrict its growth and spread. Trichoderma spp. produces many antibiotics, viz. trichodermin, trichodermol, trichotoxin and harzianolide, which have inhibitory effect against fungal growth and sporulation (Yonas and Amare 2008). Trichoderma species produce many extracellular enzymes including chitinase, pectinase, amylase, and protease, which help in the degradation of cell wall of pathogenic fungi and many Trichoderma species are also reported to produce siderophores and indole acetic acid (Sallem et al. 2021). The siderophores produced by bio-control fungi can utilize the limited available iron and hence reduced its availability for the pathogenic fungi (Sallem et al. 2021). Bacterial antagonist, B. subtilis, has the potential to produce antimicrobial peptide substances, viz. subtilin, bacilysin, mycobacillisyn, and iturin, which can change hyphal morphology including hyphal swelling, distortion and cytoplasm aggregation in hyphal cells of C. acutatum and C. gloeosporioides (Yoshida et al. 2001). Spray application of bacterial filtrate of Streptomyces aureofaciens on mango trees was effective to manage anthracnose disease (Haggag et al. 2011). Antibiotic metabolites produced by bacterial antagonists can enter the protoplasm of hyphal cells, resulting in dissolution and disintegration and finally causing malformation of mycelium (Rahman et al. 2007).

Yeast antagonists also have the potential to be used as bio-control agent for the management of plant diseases (Abo-Elyousr et al. 2021). Yeast antagonists can grow quickly and colonize host-surface quickly and efficiently, which limit the availability of nutrient and space to pathogen (Abo-Elyousr et al. 2021). 


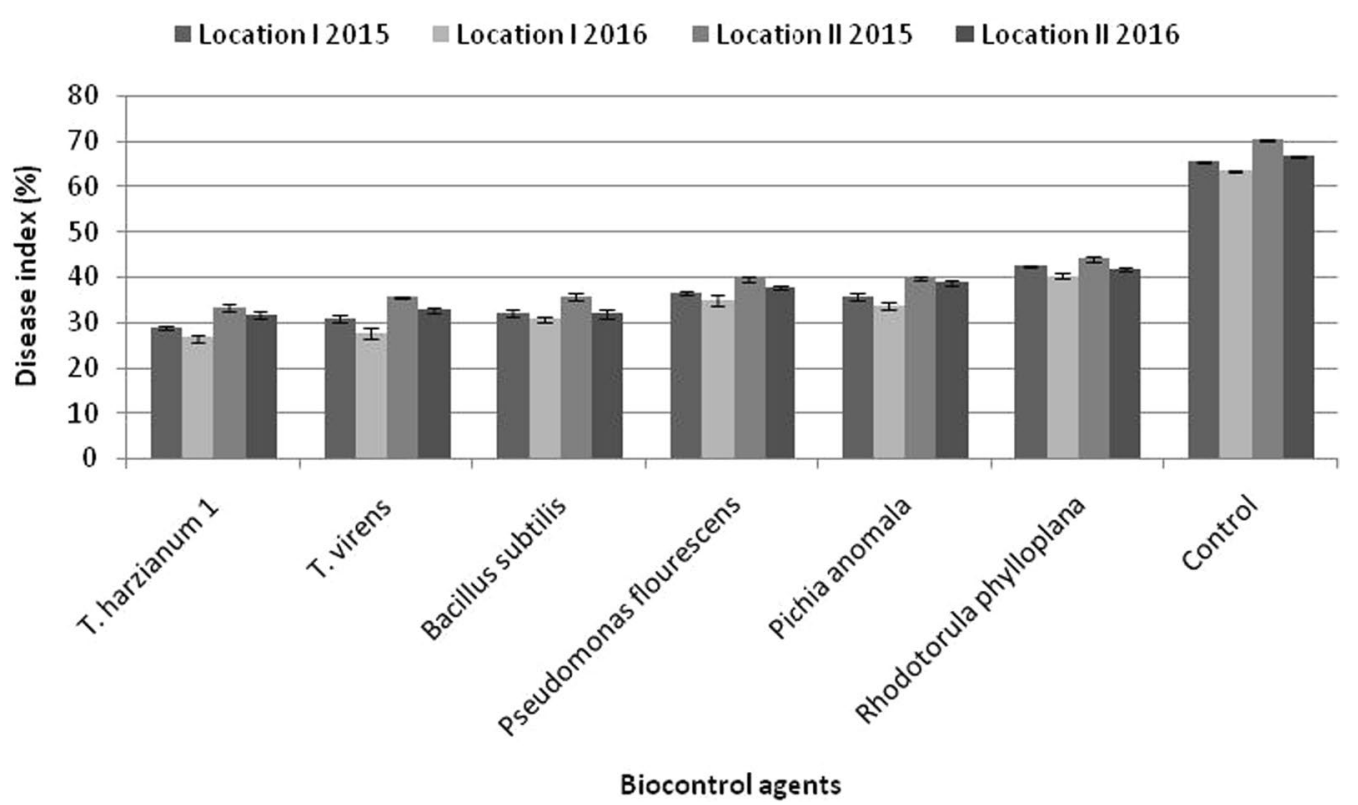

Fig. 6 Effect of bio-control agents on anthracnose development on mango fruits under field conditions

Additionally, yeast antagonists produce few secondary metabolites, which may significantly affect the ability of other fungi to produce cell wall degrading enzymes and may hydrolyse the conidia of plant pathogenic fungi ( $\mathrm{Li}$ et al. 2019). The bio-control potential of different yeast antagonists, viz. P. guilliermondii, Candida musae, Issatchenkia orientalis and C. quercitrus, had been demonstrated against chilli anthracnose caused by $C$. capsici (Chanchaichaovivat et al. 2008). Antagonistic activities of yeasts may be due to competition for nutrients, site exclusion, direct parasitism and may also be due to resistance induction in plants (Hashem et al. 2008). The present study emphasized on practical application of biological control agents to manage the mango anthracnose under field conditions. The effectiveness of biological control agents to manage mango anthracnose disease provided an environment-friendly approach for the production of pesticide-free mango fruits.

\section{Conclusions}

The explorations of various bio-control agents to control various plant diseases could be of significant agronomic importance. The bio-formulation application of T. harzianum, B. subtilis and $P$. anomala could be used as eco-friendly future approach for the management of pre- and post-harvest anthracnose on mango.

\section{Abbreviations}

ITS: Internal transcribed spacers; PDA: Potato dextrose agar; CTAB: Cetyl trimethyl ammonium bromide; BLAST: Basic local alignment search tool; PDC: Percentage disease control.

\section{Supplementary Information}

The online version contains supplementary material available at https://doi. org/10.1186/s41938-021-00480-9.

Additional file 1: Mango Anthracnose Biocontrol Egyptian Feb 2021 Supple data. Fig. 1s. Symptomatology of Colletotrichum gloeosporioides causing mango anthracnose on leaves and fruits, Fig. 2s. a) Culture b) septate mycelium c) conidia of Colletotrichum gloeosporioides, Fig. 3s. Evaluation of bio-control agents against the mycelial growth of Colletotrichum gloeosporioidesi, Fig. 4s. Effect of fruit dip treatment with bio-control on mango anthracnose. Photographs of different experiments are depicted in these figures

\section{Acknowledgements}

The authors are thankful to the Department of Plant Pathology, Dr. Yaswant Singh Parmar University of Horticulture and Forestry Nauni, Solan (H.P.), for conferring the laboratory and glasshouse facilities as well as the Associate Director of Regional Horticultural Research and Training Station (RHR\&TS), Dhaula Kuan (Sirmour) and Regional Horticulture Research and Training Station (RHR\&TS), Jachh (Nurpur), (H.P.), for providing the field facilities for pursuing this study.

\section{Authors' contributions}

AS, IMS and MS conceived and designed the experiments. AS performed the experiments. KS and AS analysed the data. AS and MS wrote the paper. IMS, AS and MS contributed to the critical review and editing of the manuscript. All authors read and approved the final manuscript.

\section{Funding}

Not applicable. 


\section{Availability of data and materials}

The datasets used and/or analysed during the current study are available from the corresponding author on reasonable request.

\section{Declarations}

\section{Ethics approval and consent to participate}

Not applicable.

\section{Consent for publication}

Not applicable.

\section{Competing interests}

The authors declare that they have no competing interests.

\section{Author details}

${ }^{1}$ Department of Plant Pathology, Dr YS Parmar University of Horticulture \& Forestry (Solan), Nauni, Himachal Pradesh, India. ${ }^{2}$ Department of Basic Science (COHF, Neri), Dr YS Parmar University of Horticulture \& Forestry (Solan), Nauni, Himachal Pradesh, India.

Received: 21 June 2021 Accepted: 9 October 2021

Published online: 20 October 2021

\section{References}

Abo-Elyousr KAM, Al-Qurashi AD, Almasoudi NM (2021) Evaluation of the synergy between Schwanniomyces vanrijiae and propolis in the control of Penicillium digitatum on lemons. Egypt J Biol Pest Control 31:66

Aneja KR (2003) Experiments in microbiology, plant pathology and biotechnology. New Age International Ltd., New Delhi

Bartnett HL (1972) Illustrated genera of Imperfect fungi. Burgress Publishing Co, Minnesota, pp 152-153

Begum MM, Sariah M, Abidin ZMA, Puteh BA, Rahman AM (2008) Antagonistic potential of selected fungal and bacterial biocontrol agents against Colletotrichum truncatum of soybean seeds. Pertanica J Trop Agric Sci 31:45-53

Berardini N, Fezer R, Conrad J, Beifuss U, Carle R, Schieber A (2005) Screening of mango (Mangifera indica L.) cultivars for their contents of flavonol O- and xanthone C-glycosides, anthocyanins, and pectin. J Agric Food Chem 53:1563-1570

Chanchaichaovivat A, Panijpan B, Ruenwongsa P (2008) Putative modes of action of Pichia guilliermondii strain R13 in controlling chilli anthracnose after harvest. Biol Control 47:207-215

Dhingra OD, Sinclair JB (1995) Basic plant pathology methods. Lewis, London

Elad Y, Barak R, Henis Y (1983) Ultrastructural studies of the interaction between Trichoderma spp. and plant pathogenic fungi. J Phytopathol 107:168-175

Gomez KA, Gomez AA (1984) Statistical procedures for agricultural research. Wiley, New York, p 680

Gud MA, Raut SP (2008) Control of mango anthracnose and stem end rot fungi by fungicides and bioagents. J Maharashtra Agric Univ 33(1):120-122

Haggag WM, Mohamed EM, Azzazy AME (2011) Optimization and production of antifungal hydrolysis enzymes by Streptomyces aureofaciens against Colletotrichum gloeosporioides of mango. Agricultural Sci 2(2):146-157

Hashem M, Omran YAMM, Sallam NMA (2008) Efficacy of yeasts in the management of root-knot nematode Meloidogyne incognita, in flame seedless grape vines and the consequent effect on the productivity of the vines. Biocontrol Sci Technol 18:357-375
Huang HC, Hoes JA (1976) Penetration and infection of Sclerotinia sclerotium by Coiniothyrium minitans. Can J Bot 54:406-410

Johnson LA (1957) Effect of antibiotics of the members of bacteria and fungi isolated from soil by dilution plate method. Phytopathology 47:630

Kumar S, Stecher G, Li M, Knyaz C, Tamura K (2018) MEGA X: molecular evolutionary genetics analysis across computing platforms. Mol Biol Evol 35:1547-1549

Li J, Li H, Ji S, Chen T, Tian S, Qin G (2019) Enhancement of biocontrol efficacy of Cryptococcus laurentii by cinnamic acid against Penicillium italicum in citrus fruit. Postharvest Biol Technol 149:42-49

Ma Z, Michailides TJ (2005) Advances in understanding molecular mechanisms of fungicide resistance and molecular detection of resistant genotypes in phytopathogenic fungi. Crop Prot 24:853-863

Mckinney HH (1923) Influence of soil temperature and moisture on infection of wheat seedling by Helminthosporium sativum. Jagric Res 26:195-217

Murray MG, Thompson WF (1980) Rapid isolation of high molecular weight plant DNA. Nucleic Acids Res 8:4321-4325

Prabakar K, Raguchander T, Saravanakumar D, Muthulakshmi P, Parthiban VK, Prakasam V (2008) Management of postharvest disease of mango anthracnose incited by Colletotrichum gleosporioides. Arch Phytopathol Plant Protec 41(5):333-339

Prasad RD, Rangeshwaram R (2000) Shelf life and bioefficacy of Trichoderma harzianum formulated in various carrier materials. Plant Dis Res 15:38-42

Rahman MA, Kadir J, Mahmud TMM, Rahman RA, Begum MM (2007) Screening of antagonistic bacteria for biocontrol activities on Colletotrichum gloeosporioides in papaya. Asian J Plant Sci 6:12-20

Rifai MA (1969) A revision of the genus Trichoderma. Mycol Pap 116:1-56

Saharan B, Nehra V (2011) Plant growth promoting rhizobacteria: a critical review. Life Sci Med Res 21:30

Saeed E, Sham A, El-Tarabily KA, Abu Elsamen F, Iratni R, AbuQamar SF (2016) Chemical control of black scorch disease on date palm caused by the fungal pathogen, Thielaviopsis punctulata, in United Arab Emirates. Plant Dis 100:2370-2376

Sallam N, Ali EF, Seleim MAA, Bagy HMMK (2021) Endophytic fungi associated with soybean plants and their antagonistic activity against Rhizoctonia solani. Egypt J Biol Pest Control 31:54

Saraf M, Pandya U, Thakkar A (2014) Role of allelochemicals in plant growth promoting rhizobacteria for biocontrol of phytopathogens. Microbiol Res 169:18-29

Sundravadana S, Alice D, Kuttalam S, Samiyappan R (2007) Efficacy of azoxystrobin on Colletotrichum gloeosporioides Penz. growth and on controlling mango anthracnose. J Agric Biol Sci 2(3):11-15

Syed Ab Rahman SF, Singh E, Pieterse CMJ, Schenk PM (2018) Emerging microbial biocontrol strategies for plant pathogens. Plant Sci 267:102-111

Udhayakumar R, Usha Rani S (2010) In vitro efficacy of bacterial antagonists on the incidence of mango anthracnose and development of its pathogen. Agric Sci Digest 30(4):293-295

Utkhede RS, Rahe JE (1983) Interactions of antagonists and pathogens in biological control of onion white rot. Phytopathology 73:890-892

Vincent JM (1947) Distortion of fungal hyphae in the presence of certain inhibitors. Nature 150:850

Yonas K, Amare A (2008) Postharvest biological control of anthracnose (Colletotrichum gloeosporioides) on mango (Mangifera indica). Postharvest BiolTechnol 50:8-11

Yoshida S, Hiradate S, Tsukamato T, Hatakeda K, Shirata A (2001) Antimicrobial activity of culture filtrate Bacillus amyloliquefaciens RC-2 isolated from mulberry leaves. Phytopathology 91:181-187

\section{Publisher's Note}

Springer Nature remains neutral with regard to jurisdictional claims in published maps and institutional affiliations. 